\title{
Studies on Amino Acid Contents of Processed Soybean
}

\section{Part X. The Influence of Added Sugars on the Heat Destruction of the Basic and Sulphur Containing Amino Acids in Soybean Products}

\author{
By Harue TaIra \\ Food Research Institute, Ministry of Agriculture and Forestry, \\ Fukagawa, Koto-ku, Tokyo \\ Received February 21, 1966
}

\begin{abstract}
The influence of sugars on the heat destruction of the basic and sulphur containing amino acids of soybean products, soybean protein and also pure amino acids has been investigated.

Amino acids were estimated by microbiological assay procedure. Cystine was also determined chromatographically.

Lysine, arginine and histidine were destroyed in different ways behaved when soybean products, soybean protein or pure amino acids mixed with and without sugars were autoclaved; and the condition of added sugars tended to influence the way of destruction.

Cystine was the most heat-labile amino acid. But the destruction did not appear to be ascribed to added sugars except $50 \%$ ethyl alcohol-soluble sugar solution of defatted soybean flour. This finding was also substantiated by the chromatographic analysis.

Methionine, in soybean products and soybean protein or as pure amino acid with and without the addition of sugars, was not influenced by autoclaving.
\end{abstract}

\section{INTRODUCTION}

In the previous publications ${ }^{1,2}$ ) of this series, it was shown that several amino acids, such as cystine, lysine, arginine, tryptophan and serine, were destroyed during autoclaving of defatted soybean flour. It was considered that a cause of the amino acid destruction was apparently influenced by the carbohydrates present in defatted soybean flour. Several studies $^{3 \sim 12)}$ showed that soybean oil meal, 1) H. Taira, H. Taira, K. Sugimura and Y. Sakurai, This Journal, 29, 1074 (1965).

2) H. Taira, H. Taira, K. Sugimura and Y. Sakurai, ibid., 29, 1080 (1965).

3) L. Peck, "The composition and nutritive properties of soybeans and soybean oil meal", (J. W. Hayward, J. E. Hunter, H. E. Robinson, K. J. Seulke and L. Kishlar Ed.) Soybean Nutritional Research Council, Chicago, 1939, p. 28

4) J. P. Street and E. M. Bailey, J. Ind. Eng. Chem., 7, 853

5) M. Yukawa, J. Tokyo Chem. Soc., 38, 318 (1917)

6) R. J. Evans and H. A. Butts, J. Biol. Chem., 175, 15 (1948)

${ }_{7}^{7}$ R. J. Evans and H. A. Butts, Food Research, 16, 415

8) R. J. Evans, S. L. Bandemer and D. H. Bauer, J. Food Sci., 26, 663 (1961).

9) R. J. Evans, A. C. Groschke and H. A. Butts, Arch. Biochem., 30, 414 (1951). when autoclaved at 15 pounds pressure for 4 hours, suffered a loss of $41 \sim 43 \%$ lysine, $35 \%$ arginine, $31 \sim 47 \%$ cystine, $17 \%$ histidine and $16 \%$ tryptophan, but in soybean protein, the loss was $3 \%$ lysine, $5 \%$ cystine, $6 \%$ histidine, $7 \%$ tryptophan and $2 \%$ methionine. On the other hand, when soybean protein was autoclaved with the carbohydrates, the addition of sucrose and glucose destroyed a large amount of the basic amino acids, but no destruction of cystine and other amino acids occurred. However, the addition of dextrin, agar-agar, gum arabic and soybean oil had no appreciable effect on the destruction of the amino acids. But the amount of carbohydrates used by Evans et al. ${ }^{6 \sim 12)}$ was so large that it is

\footnotetext{
10) R. J. Evans, S. L. Bandemer and D. H. Bauer, $f . A g r$. Food Chem., 8, 383 (1960).

11) R. J. Evans, S. L. Bandemer and D. H. Bauer, ibid., 1o, 416 (1962).

12) R. J. Evans and H. A. Butts, J. Biol. Chem., 178, 543 (1949).
} 
not considered as a suitable amount to study the destruction of amino acids by added carbohydrates. In their results, ${ }^{9 \sim 11)}$ it was noticeable that cystine was destroyed when soybean oil meal was autoclaved but not when Alpha protein or protein plus various carbohydrates or oil were autoclaved. For this reason, Evans et al. ${ }^{9)}$ postuiated that destruction of cystine was not caused by some constituents peculiar to soybean oil meal. But in earlier work of Evans et al.,11) it was suggested that Alpha protein contains less than half as much cystine as does the total protein of soybean meal. The fact may be apparently due to the destruction of cystine during processing of Alpha protein preparation.

On the other hand, Kamada et al. ${ }^{13)}$ reported that when $50 \%$ ethyl alcohol extracted defatted soybean flour was steamed with sucrose, D-glucose, raffinose, stachyose, D-xylose, or $50 \%$ ethyl alcohol-soluble sugar solution of defatted soybean flour, the surface colour was similar to that of soybean flour under the same heating condition. As a result, it is considered that the sugars extracted by $50 \%$ ethyl alcohol give not only the colouration but also the destruction of amino acid on the heat treatment of soybean flour.

The present investigation is the outgrowth of an attempt to determine the cause of lysine, arginine, histidine, cystine, and methionine destruction when soybean flour is autoclaved.

\section{EXPERIMENTAL}

\section{Materials}

1) Defatted soybean flour. Defatted soybean flour described in the previous paper $^{1)}$ was used and the general composition was as follows: crude protein, $46.8 \%$ (nitrogen $\times 6.25$ ); oil, $0.35 \%$; moisture, $8.6 \%$; and total sugar, ${ }^{14)} 22.5 \%$.

2) $50 \%$ ethyl alcohol extracted defatted soy13) H. Kamada and Y. Sakurai, Nôsan Kakô Gijutsu Kenkŷ Kaishi, 5,50 (1958).

14) A. 'W. Van der Haar, "Anleitung zum Nachweis, zur Trennung und Bestimmung der Monosaccharide und Aldehydsauren", Berlin, 1920 , p. 120 . bean flour (EAES)*. Defatted soybean flour was extracted with $50 \%$ ethyl alcohol until the eluent colour was light. ${ }^{13)}$ The contents of crude protein and total sugar ${ }^{14)}$ in this sample were $54.9 \%$ (nitrogenx $6.25)$ and $13.4 \%$, respectively.

3) Glycinin. Glycinin was prepared by the extraction method of Akabori et al.15) and was lyophilized. The content of crude protein was $88.8 \%$ (nitrogenx 6.25).

4) Pure amino acids. L-Lysine monohydrochloride, L-arginine monohydrochloride, L-histidine monohydrochloride, L-cystine monohydrochloride and Lmethionine were obtained from G.B.I. Co. These amino acids were used individually or as a mixture.

5) Added sugars. The added sugars were as follows: sucrose, raffinose, D-glucose, D-xylose, or their mixture and $50 \%$ ethyl alcohol-soluble sugar solution (ES)* which was obtained by the extraction of defatted soybean flour. ${ }^{132}$

Addition of sugars and water to soybean products, soybean protein and pure amino acids.

The added amounts of the sugars and water to the soybean products, soybean protein and pure amino acids are listed in Table $I$. The amount of the sugars was calculated on the same ratio based on the protein or amino acids as found in soybean..$^{3 \sim 5)}$ Stachyose was not available for use in this experiment.

In the experiment, the quantity of water added was 10 times the weight of defatted soybean flour, and in the case of other samples, the amount of added water was calculated to give the same ratio with that to protein or the amino acids in the defatted soybean flour.

Heat treatment, acid hydrolysis and determination of amino acids.

The samples were autoclaved for 4 hours at $1.4 \mathrm{Kg} /$ $\mathrm{cm}^{2}\left(126^{\circ} \mathrm{C}\right)$ pressure. To the heat-treated samples concentrated hydrochloric acid was added to give a $4 \mathrm{~N}$ aqueous hydrochloric acid solution in the mixture. The acid hydrolysis and determination of amino acids were similar to those used in the previous study." Cystine determination was done not only by the micro. biological assay method but also by the chromatographic procedure of Schram et al. ${ }^{10)}$

* Seven hundred and eighty $g$ of EAES and $390 \mathrm{ml}$ of ES were obtained from $1000 \mathrm{~g}$ of defatted soybean flour.

15) S. Akabori and S. Mizushima Ed., "Chemistry of Protein", Kyôritsu Shuppan Co., Ltd., 1955, Vol.' III, p. 18.

16) E. Schram, S. Moore and E. J. Bigwood, Biochem. J., 57, 33 (1954). 
Table I. Added Ratio of Sugars and Water to Soybean Products and Amino Aci Reagents"
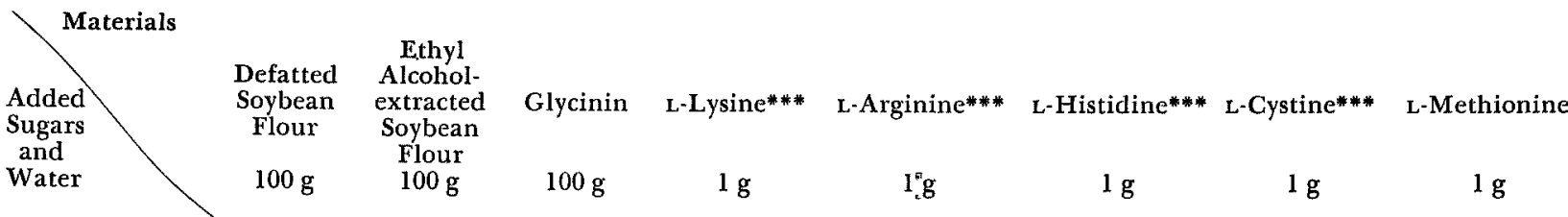

Amino Acid

Mixture $1 \mathrm{~g}$

Flour Soybean

100

$1 \mathrm{~g}$

$I_{\llcorner}^{m} \mathrm{~g}$

$1 \mathrm{~g}$

$1 \mathrm{~g}$

L-His**** $0.43 \mathrm{~g}$

Sucrose

$0(\mathrm{~g}) \quad 7.32(\mathrm{~g})$

$11.84(\mathrm{~g})$

$1.90(\mathrm{~g})$

$1.90(\mathrm{~g})$

4.42 (g)

$11.11(\mathrm{~g})$

0.38

0.88

2.22

0.470

0.076

0.177

0.444

0.470

0.076

0.076

0.177

0.444

14.22

2.43
$13(\mathrm{ml})$

5.66

$76(\mathrm{ml})$

$0(\mathrm{ml}) \quad 50(\mathrm{ml})$

15.16
$81(\mathrm{ml})$

$13(\mathrm{ml})$

$30(\mathrm{ml})$

$320(\mathrm{ml})$

$746(\mathrm{ml})$

$1860(\mathrm{ml})$

1784

$\begin{array}{ll}\text { L-Cys**** } & 0.17 \mathrm{~g} \\ \text { L-Met } & 0.13 \mathrm{~g}\end{array}$

Water for ES 1180

1899

307

307

716

$14.70(\mathrm{~g})$

$1.90(\mathrm{~g})$

0.38

$\begin{array}{ll}2.94 & 0.076\end{array}$

0.588

0.076
0.076

18.82

2.43

$100(\mathrm{ml})$

$13(\mathrm{ml})$

* Sugar and amino acid contents in soybean on a basis of calculation were as follows: sucrose $5 \%$, raffinose $1 \%$ and reduced sugars (glucose $0.2 \%$ and

* xylose $0.2 \%$ ) in raw material, and lysine $7 \%$, arginine $7 \%$, histidine $3 \%$, cystine $1.2 \%$ and methionine $0.9 \%$ in protein $(\mathrm{N} \times 6.25)$

*** L-Lysine, L-arginine, L-bistidine and L-cystine are calculated as solution.

Table II. Effect of Autoclaving on Lysine in Soybean Products and Amino Acid Reagents

$\begin{array}{llcc}\text { Meat } & \begin{array}{c}\text { Added } \\ \text { Materials }\end{array} & \begin{array}{c}\text { Lysine } \\ \text { Content } \\ \text { g/16 gN }\end{array} & \begin{array}{c}\text { Lysine } \\ \text { Remains } \\ \text { \% of } \\ \text { Total } \\ \text { Soybean } \\ \text { Flour }\end{array} \\ \text { None } & \text { None } & 6.93 & 100 \\ \text { Autoclaved } & \text { None } & 5.54 & 80 \\ \text { Autoclaved } & \text { Sucrose } & - & - \\ \text { Autoclaved } & \text { Raffinose } & - & - \\ \text { Autoclaved } & \text { D-Glucose } & - & - \\ \text { Autoclaved } & \text { D-Xylose } & - & - \\ \text { Autoclaved } & \text { Mixture } & - & - \\ \text { Autoclaved } & \text { ES } & - & -\end{array}$

$\begin{array}{cc}\begin{array}{c}\text { Ethyl Alcohol- } \\ \text { extracted } \\ \text { Defatted } \\ \text { Soybean }\end{array} \\ \begin{array}{c}\text { Lysine } \\ \text { Content }\end{array} & \begin{array}{c}\text { Lysine } \\ \text { Remains } \\ \text { \% of } \\ \text { g/16 gN }\end{array} \\ \begin{array}{cc}\text { Total } \\ 6.84\end{array} & 100 \\ 6.65 & 97 \\ 6.38 & 93 \\ 6.53 & 95 \\ 6.45 & 94 \\ 6.32 & 92 \\ 6.19 & 90 \\ 6.36 & 93\end{array}$

\begin{tabular}{|c|c|}
\hline $\begin{array}{l}\text { Lysine } \\
\text { Content } \\
\mathrm{g} / 16 \mathrm{gN}\end{array}$ & $\begin{array}{c}\text { Lysine } \\
\text { Remain } \\
\% \text { of } \\
\text { Total }\end{array}$ \\
\hline 5.95 & 100 \\
\hline 5.80 & 97 \\
\hline 5.58 & 94 \\
\hline 5.54 & 93 \\
\hline 5.56 & 93 \\
\hline 5.42 & 91 \\
\hline 5.35 & 90 \\
\hline 5.28 & 89 \\
\hline
\end{tabular}

$\begin{array}{cc}\begin{array}{c}\text { Lysine } \\ \text { Content } \\ \mathrm{mg} / \mathbf{1 0 0 \mathrm { ml }}\end{array} & \begin{array}{c}\text { Lysine } \\ \text { Remains } \\ \% \text { of } \\ \text { Total }\end{array} \\ 313 & 100 \\ 303 & 97 \\ 304 & 97 \\ 302 & 96 \\ 301 & 96 \\ 307 & 98 \\ 300 & 96 \\ 293 & 94\end{array}$

$\begin{array}{cc}\begin{array}{c}\text { Amino Acid } \\ \text { Mixture }\end{array} \\ \begin{array}{c}\text { Lysine } \\ \text { Content }\end{array} & \begin{array}{c}\text { Lysine } \\ \text { Remains } \\ \text { \% } / 100 \mathrm{ml} \text { of } \\ \text { Total }\end{array} \\ 313 & 100 \\ 285 & 91 \\ 288 & 92 \\ 301 & 96 \\ 285 & 91 \\ 299 & 96 \\ 297 & 95 \\ 287 & 92\end{array}$




\section{RESULTS AND DISCUSSION}

The effect of autoclaving on amino acid contents, in the presence of sugars, is shown in Table II for lysine, Table III for arginine, Table IV for histidine, Table $\mathrm{V}$ for cystine and Table VII for methionine. Amino acid values are expressed as $\mathrm{g}$ per $16 \mathrm{~g}$ nitrogen in the original defatted soybean flour, EAES and glycinin and as $\mathrm{mg}$ per $100 \mathrm{ml}$ of the original solution on pure amino acids. The residual quantities are expressed as the percentage of the original amount.

The destruction of lysine.

When defatted soybean flour was autoclaved, $20 \%$ of lysine was destroyed. When EAES or glycinin were autoclaved individually, the destruction did not occur, but addition of sucrose, raffinose, D-glucose, D-xylose, sugar mixture or ES caused destruction of lysine. Further, in the case of EAES and glycinin, there is no significant difference between them in the amount of destruction or kinds of additional sugars.

When merely L-lysine hydrochloride solution was autoclaved or as the amino acid mixture, no destruction of lysine took place, but with sugars, L-lysine hydrochloride solution and the amino acid mixture showed lysine destruction of $2 \sim 6 \%$ and $4 \sim 9 \%$, respectively.

On the heat destruction of lysine, Evans et al. ${ }^{6 \sim 8)}$ observed that approximately $40 \%$ of the lysine in the soybean oil meal was destroyed by autoclaving at 15 p.s.i. $(1.05 \mathrm{Kg}$ / $\mathrm{cm}^{2}$ ) for 4 hours. However, in comparison with the data in the present paper, values reported by Evans et al. are higher even though the heating condition in their investigations is milder. The difference between the destroyed lysine values may be due to the difference in the water content in the samples. Evans et al. ${ }^{6-8)}$ did not use additional water, but in the present experiment water of 10 times the weight of the defatted soybean flour has been added. Regarding this phenomenon, it was previously reported that the moisture content of the defatted soybean flour had in fluence upon the lysine destruction on auto. claving. ${ }^{2)}$

On the effect of the kinds of added carbohydrates, Evans et al.6) reported that sucrose was appearently the cause of most of the lysine destruction which occurred when soybean oil meal was autoclaved. But in the results of the present experiment, the addition of sugars equivalent in amount as that contained in soybean to soybean products, soybean protein and pure amino acid did not cause appreciable loss of lysine. Evans et al. used $2 \mathrm{~g}$ of carbohydrates to $8 \mathrm{~g}$ of soybean protein and consequently, the destruction of lysine was increased. It appears that the lysine destruction in defatted soybean flour is not solely due to the presence of sucrose in the flour.

\section{The destruction of arginine}

Thirteen percent of arginine in defatted soybean flour was destroyed during autoclaving. In EAES or glycinin, there was no destruction of arginine whether sucrose, raffinose, D-glucose, D-xylose, sugar mixture, or ES was added or not. In L-arginine hydrochloride solution, there was no destruction by autoclaving, but when above-mentioned sugars were added to the sample, the destruction was caused by the addition of sugar mixture and ES. In the amino acid mixture, the destruction was found when sucrose, raffinose, D-glucose, sugar mixture, or ES was added to sample (Table III).

Evans et al. ${ }^{7}$ observed that autoclaving soybean oil meal for 4 hours at 15 p.s.i. (1.05 $\mathrm{Kg} / \mathrm{cm}^{2}$ ) destroyed $35 \%$ of arginine, whereas in our earlier investigations ${ }^{1,2}$ ) we had reported a smaller loss. In this case also the degree of destruction depends on two factors similar to those quoted for lysine. The primary cause is the difference in the quantity of 
Table III. Effect of Autoclaving on Arginine in Soybean Products and Amino Agid Reagents

\begin{tabular}{|c|c|c|c|c|c|c|c|c|c|c|c|}
\hline \multirow[b]{2}{*}{$\begin{array}{l}\text { Heat } \\
\text { Treatment }\end{array}$} & \multirow{2}{*}{$\begin{array}{l}\text { Materials } \\
\text { Added } \\
\text { Sugars }\end{array}$} & \multicolumn{2}{|c|}{$\begin{array}{c}\text { Defatted Soybean } \\
\text { Flour }\end{array}$} & \multicolumn{2}{|c|}{$\begin{array}{l}\text { Ethyl Alcohol- } \\
\text { extracted } \\
\text { Defatted } \\
\text { Soybean Flour }\end{array}$} & \multicolumn{2}{|c|}{ Glycinin } & \multicolumn{2}{|c|}{ L-Arginine } & \multicolumn{2}{|c|}{$\begin{array}{l}\text { Amino Acid } \\
\text { Mixture }\end{array}$} \\
\hline & & $\begin{array}{l}\text { Arginine } \\
\text { Content } \\
\mathrm{g} / 16 \mathrm{gN}\end{array}$ & $\begin{array}{c}\text { Arginine } \\
\text { Remains } \\
\text { \% of } \\
\text { Total }\end{array}$ & $\begin{array}{l}\text { Arginine } \\
\text { Content } \\
\mathrm{g} / 16 \mathrm{gN}\end{array}$ & $\begin{array}{c}\text { Arginine } \\
\text { Remains } \\
\% \text { of } \\
\text { Total }\end{array}$ & $\begin{array}{c}\text { Arginine } \\
\text { Content } \\
\mathrm{g} / 16 \mathrm{gN}\end{array}$ & $\begin{array}{c}\text { Arginine } \\
\text { Remains } \\
\% \text { of } \\
\text { Total }\end{array}$ & $\begin{array}{c}\text { Arginine } \\
\text { Content } \\
\mathrm{mg} / 100 \mathrm{ml}\end{array}$ & $\begin{array}{c}\text { Arginine } \\
\text { Remains } \\
\% \text { of } \\
\text { Total }\end{array}$ & $\begin{array}{c}\text { Arginine } \\
\text { Content } \\
\mathrm{mg} / 100 \mathrm{ml}\end{array}$ & $\begin{array}{c}\text { Arginine } \\
\text { Remains } \\
\% \text { of } \\
\text { Total }\end{array}$ \\
\hline None & None & 6.97 & 100 & 6.81 & 100 & 6.63 & 100 & 313 & 100 & 313 & 100 \\
\hline Autoclaved & None & 6.06 & 87 & 6.70 & 98 & 6.68 & 101 & 304 & 97 & 297 & 95 \\
\hline Autoclaved & Sucrose & - & - & 6.80 & 100 & 6.58 & 99 & 302 & 96 & 260 & 83 \\
\hline Autoclaved & Raffinose & - & - & 6.75 & 99 & 6.86 & 103 & 302 & 96 & 286 & 91 \\
\hline Autoclaved & D-Glucose & - & - & 6.80 & 100 & 6.87 & 104 & 306 & 98 & 287 & 92 \\
\hline Autoclaved & D-Xylose & - & - & 6.97 & 102 & 6.50 & 98 & 301 & 96 & 297 & 95 \\
\hline Autoclaved & Mixture & - & - & 6.71 & 99 & 6.50 & 98 & 277 & 89 & 275 & 88 \\
\hline Autoclaved & ES & - & - & 6.70 & 98 & 6.87 & 104 & 271 & 87 & 275 & 88 \\
\hline
\end{tabular}

Table IV. Effegt of Autoglaving on Histidine in Soybean Products and Amino Agid Reagents

\begin{tabular}{|c|c|c|c|c|c|c|c|c|c|c|c|}
\hline \multirow[b]{2}{*}{$\begin{array}{l}\text { Heat } \\
\text { Treatment }\end{array}$} & \multirow[t]{2}{*}{ Materials } & \multicolumn{2}{|c|}{$\begin{array}{c}\text { Defatted Soybean } \\
\text { Flour }\end{array}$} & \multicolumn{2}{|c|}{$\begin{array}{l}\text { Ethyl Alcohol- } \\
\text { extracted } \\
\text { Defatted } \\
\text { Soybean Flour }\end{array}$} & \multicolumn{2}{|c|}{ Glycinin } & \multicolumn{2}{|c|}{ L-Histidine } & \multicolumn{2}{|c|}{$\begin{array}{c}\text { Amino Acid } \\
\text { Mixture }\end{array}$} \\
\hline & & $\begin{array}{l}\text { Histidine } \\
\text { Content } \\
\mathrm{g} / 16 \mathrm{gN}\end{array}$ & $\begin{array}{c}\text { Histidine } \\
\text { Remains } \\
\% \text { of } \\
\text { Total }\end{array}$ & $\begin{array}{l}\text { Histidine } \\
\text { Content } \\
\mathrm{g} / 16 \mathrm{gN}\end{array}$ & $\begin{array}{l}\text { Histidine } \\
\text { Remains } \\
\% \text { of } \\
\text { Total }\end{array}$ & $\begin{array}{c}\text { Histidine } \\
\text { Content } \\
\text { g/16 gN }\end{array}$ & $\begin{array}{c}\text { Histidine } \\
\text { Remains } \\
\% \text { of } \\
\text { Total }\end{array}$ & $\begin{array}{c}\text { Histidine } \\
\text { Content } \\
\mathrm{mg} / 100 \mathrm{ml}\end{array}$ & $\begin{array}{l}\text { Histidine } \\
\text { Remains } \\
\text { \% of } \\
\text { Total }\end{array}$ & $\begin{array}{l}\text { Histidine } \\
\text { Content } \\
\mathrm{mg} / 100 \mathrm{ml}\end{array}$ & $\begin{array}{l}\text { Histidine } \\
\text { Remains } \\
\% \text { of } \\
\text { Total }\end{array}$ \\
\hline None & None & 2.97 & 100 & 2.97 & 100 & 2.56 & 100 & 134 & 100 & 134 & 100 \\
\hline Autoclaved & None & 2.92 & 98 & 2.97 & 100 & 2.61 & 102 & 130 & 97 & 132 & 99 \\
\hline Autoclaved & Sucrose & - & - & 2.91 & 98 & 2.36 & 92 & 114 & 85 & 125 & 93 \\
\hline Autoclaved & Raffinose & - & - & 2.91 & 98 & 2.41 & 94 & 127 & 95 & 132 & 99 \\
\hline Autoclaved & D-Glucose & - & - & 2.97 & 100 & 2.39 & 93 & 130 & 97 & 127 & 95 \\
\hline Autoclaved & D-Xylose & - & - & 2.89 & 97 & 2.43 & 95 & 129 & 96 & 127 & 95 \\
\hline Autoclaved & Mixture & - & - & 2.84 & 96 & 2.43 & 95 & 113 & 84 & 127 & 95 \\
\hline Autoclaved & ES & - & - & 2.91 & 98 & 2.43 & 95 & 113 & 84 & 121 & 90 \\
\hline
\end{tabular}


water added to samples before autoclaving, and the other cause is the difference in the amount of added sugars.

Reporting the effect of added carbohydrates on arginine destruction while autoclaving, Evans et al. ${ }^{7)}$ concluded that addition of sucrose and glucose to soybean protein enhanced the destruction. In the present study, no destruction occurred when EAES or glycinin was autoclaved individually or mixed with sugars. But the addition of sugar mixture, or ES to L-arginine hydrochloride solution, and the addition of sucrose, raffinose, D-glucose, D-xylose, sugar mixture, or ES to the amino acid mixture showed a tendency toward arginine destruction. Consequently, in comparison with the present study, the large amount of destruction of arginine reported by Evans et al. may be caused by non addition of water and large amount of added carbohydrates to the soybean protein.

Results obtained show that arginine destruction in defatted soybean flour is not mainly due to sucrose contained in soybean as in the case of lysine destruction.

The destruction of histidine.

When defatted soybean flour, EAES, glycinin, L-histidine hydrochloride solution or amino acid mixture was autoclaved, histidine was not destroyed, but the added sugars, i.e., sucrose, raffinose, D-glucose, $\mathrm{D}$-xylose, sugar mixture or ES, caused some increase in the amount of the destruction when mixed with those of soybean protein, pure amino acid and amino acid mixture (Table IV).

The amount of histidine destroyed was 5 $8 \%$ when the glycinin was mixed with sucrose, raffinose, D-glucose, D-xylose, sugar mixture or ES. When L-histidine hydrochloride solution was mixed with sugar mixture or ES, $15 \%$ destruction was noted but no destruction was observed when mixed with D-glucose or $\mathrm{D}$ xylose. In the amino acid mixture, the addi- tion of sugars induced the destruction of histidine.

Evans et a1.7) observed that when soybean oil meal was autoclaved at 15 p.s.i. $(1.05 \mathrm{Kg} /$ $\left.\mathrm{cm}^{2}\right)$ for 4 hours, destruction of histidine (17\%) occurred. But our earlier investigations indicated that the destruction of histidine did not take place in defatted soybean flour by autoclaving for various temperatures or time periods. ${ }^{1,2)}$ In the present experiment, histidine destruction also did not occur in defatted soybean flour by autoclaving. Evidently, it is considered that the large amount of destroyed histidine reported by Evans et al.7) was due to the autoclaving under the condition without adding water to the sample.

When soybean protein was autoclaved with sucorse or glucose, Evans et al. ${ }^{7)}$ observed that $20 \%$ of histidine was destroyed. In comparison with the destroyed value reported by Evans et al., in the present experiment, the values obtained are low and the higher values obtained by Evans et al. may be due to the excess of carbohydrates added to soybean protein.

The destruction of cystine.

During autoclaving, a large amount of destruction, ranging from 30 to $65 \%$, occurred in all samples, i.e., defatted soybean flour, EAES, glycinin, L-cystine hydrochloride solution and amino acid mixture, with and without the sugars (Table V).

Evans et al. ${ }^{8-10}$ ) observed that $31 \sim 55 \%$ of the cystine was destroyed when soybean meal was heated in the autoclave, but no destruction of that occurred when soybean protein (Alpha protein) was autoclaved alone or mixed with $20 \%$ of sucrose, glucose, dextrin, agaragar, gum arabic, or soybean oil. In the present experiment, a large amount of cystine was destroyed by autoclaving irrespective of the sample, and the destruction was not increased by added sugars except ES. These results were 
Table V. Effect of Autoclaving on Cystine in Soybean Products and Amino Acid Reagents

\begin{tabular}{|c|c|c|c|c|c|c|c|c|c|c|c|}
\hline \multirow[b]{2}{*}{$\begin{array}{c}\text { Heat } \\
\text { Treatment }\end{array}$} & \multirow{2}{*}{$\begin{array}{l}\text { Materials } \\
\text { Added } \\
\text { Sugars }\end{array}$} & \multicolumn{2}{|c|}{$\begin{array}{c}\text { Defatted Soybean } \\
\text { Flour }\end{array}$} & \multicolumn{2}{|c|}{$\begin{array}{l}\text { Ethyl Alcohol- } \\
\text { extracted } \\
\text { Defatted } \\
\text { Soybean Flour }\end{array}$} & \multicolumn{2}{|c|}{ Glycinin } & \multicolumn{2}{|c|}{ L-Cystine } & \multicolumn{2}{|c|}{$\begin{array}{l}\text { Amino Acid } \\
\text { Mixture }\end{array}$} \\
\hline & & $\begin{array}{l}\text { Cystine } \\
\text { Content } \\
\mathrm{g} / 16 \mathrm{gN}\end{array}$ & $\begin{array}{l}\text { Cystine } \\
\text { Remains } \\
\% \text { of } \\
\text { Total }\end{array}$ & $\begin{array}{l}\text { Cystine } \\
\text { Content } \\
\mathrm{g} / 16 \mathrm{gN}\end{array}$ & $\begin{array}{c}\text { Cystine } \\
\text { Remains } \\
\text { \% of } \\
\text { Total }\end{array}$ & $\begin{array}{l}\text { Cystine } \\
\text { Content } \\
\mathrm{g} / 16 \mathrm{gN}\end{array}$ & $\begin{array}{c}\text { Cystine } \\
\text { Remains } \\
\text { \% of } \\
\text { Total }\end{array}$ & $\begin{array}{c}\text { Cystine } \\
\text { Content } \\
\mathrm{mg} / 100 \mathrm{ml}\end{array}$ & $\begin{array}{c}\text { Cystine } \\
\text { Remains } \\
\% \text { of } \\
\text { Total }\end{array}$ & $\begin{array}{c}\text { Cystine } \\
\text { Content } \\
\mathrm{mg} / 100 \mathrm{ml}\end{array}$ & $\begin{array}{c}\text { Cystine } \\
\text { Remains } \\
\% \text { of } \\
\text { Total }\end{array}$ \\
\hline None & None & 1.21 & 100 & 1.17 & 100 & 1.18 & 100 & 53.7 & 100 & 53.7 & 100 \\
\hline Autoclaved & None & 0.56 & 46 & 0.60 & 51 & 0.86 & 73 & 21.4 & 40 & 23.4 & 44 \\
\hline Autoclaved & Sucrose & - & - & 0.60 & 51 & 0.81 & 69 & 18.8 & 35 & 24.3 & 45 \\
\hline Autoclaved & Raffinose & - & - & 0.60 & 51 & 0.82 & 69 & 18.8 & 35 & 22.6 & 42 \\
\hline Autoclaved & D-Glucose & - & - & 0.58 & 50 & 0.82 & 69 & 19.9 & 37 & 25.0 & 47 \\
\hline Autoclaved & D-Xylose & - & - & 0.62 & 53 & 0.86 & 73 & 17.9 & 33 & 22.4 & 42 \\
\hline Autoclaved & Mixture & - & 一 & 0.58 & 50 & 0.82 & 69 & 17.7 & 33 & 16.9 & 32 \\
\hline Autoclaved & ES & - & - & 0.56 & 48 & 0.54 & 46 & 17.4 & 32 & 16.1 & 30 \\
\hline
\end{tabular}

Table Vil. Effect of Autoglaving on Methionine in Soybean Products and Amino Acid Reagents

\begin{tabular}{|c|c|c|c|c|c|c|c|c|c|c|c|}
\hline \multirow[b]{2}{*}{$\begin{array}{l}\text { Heat } \\
\text { Treatment }\end{array}$} & Materials & \multicolumn{2}{|c|}{$\begin{array}{c}\text { Defatted Soybean } \\
\text { Flour }\end{array}$} & \multicolumn{2}{|c|}{$\begin{array}{l}\text { Ethyl Alcohol- } \\
\text { extracted } \\
\text { Defatted } \\
\text { Soybean Flour }\end{array}$} & \multicolumn{2}{|c|}{ Glycinin } & \multicolumn{2}{|c|}{ L-Methionine } & \multicolumn{2}{|c|}{$\begin{array}{l}\text { Amino Acid } \\
\text { Mixture }\end{array}$} \\
\hline & $\begin{array}{l}\text { Added } \\
\text { Sugars }\end{array}$ & $\begin{array}{l}\text { Methionine } \\
\text { Content } \\
\mathrm{g} / 16 \mathrm{gN}\end{array}$ & $\begin{array}{c}\text { Methionin } \\
\text { Remains } \\
\text { \% of } \\
\text { Total }\end{array}$ & $\begin{array}{l}\text { Methionine } \\
\text { Content } \\
\text { g/l6 gN }\end{array}$ & $\begin{array}{l}\text { Methionine } \\
\text { Remains } \\
\text { \% of } \\
\text { Total }\end{array}$ & $\begin{array}{l}\text { Methionine } \\
\text { Content } \\
\mathrm{g} / 16 \mathrm{gN}\end{array}$ & $\begin{array}{l}\text { Methionine } \\
\text { Remains } \\
\% \text { of } \\
\text { Total }\end{array}$ & $\begin{array}{l}\text { Methionine } \\
\text { Content } \\
\mathrm{mg} / 100 \mathrm{ml}\end{array}$ & $\begin{array}{c}\text { Methionin } \\
\text { Remains } \\
\% \text { of } \\
\text { Total }\end{array}$ & $\begin{array}{l}\text { Methionine } \\
\text { Content } \\
\mathrm{mg} / 100 \mathrm{ml}\end{array}$ & $\begin{array}{c}\text { Methionine } \\
\text { Remains } \\
\text { \% of } \\
\text { Total }\end{array}$ \\
\hline None & None & 0.94 & 100 & 1.04 & 100 & 1.10 & 100 & 40.3 & 100 & 40.3 & 100 \\
\hline Autoclaved & None & 0.91 & 97 & 1.00 & 96 & 1.06 & 96 & 39.2 & 97 & 39.5 & 98 \\
\hline Autoclaved & Sucrose & - & - & 1.02 & 98 & 1.10 & 100 & 39.2 & 97 & 39.1 & 97 \\
\hline Autoclaved & Raffinose & - & - & 1.02 & 98 & 1.06 & 96 & 38.8 & 96 & 39.1 & 97 \\
\hline Autoclaved & D-Glucose & - & - & 1.00 & 96 & 1.14 & 104 & 42.5 & 105 & 38.8 & 96 \\
\hline Autoclaved & D-Xylose & - & - & 1.04 & 100 & 1.12 & 102 & 38.8 & 96 & 40.3 & 100 \\
\hline Autoclaved & Mixture & - & - & 1.00 & 96 & 1.10 & 100 & 40.3 & 100 & 40.3 & 100 \\
\hline Autoclaved & ES & - & - & 1.02 & 98 & 1.06 & 96 & 40.3 & 100 & 40.3 & 100 \\
\hline
\end{tabular}


Table VI. Comparison of Migrobiologigal and Chromatographic Methods for the Determination of Cystine

\begin{tabular}{|c|c|c|c|c|c|c|}
\hline \multirow{2}{*}{$\begin{array}{c}\text { Heat } \\
\text { Treatment }\end{array}$} & \multirow{2}{*}{$\begin{array}{l}\text { Soybean } \\
\text { Products }\end{array}$} & \multirow{2}{*}{$\begin{array}{l}\text { Added } \\
\text { Sugars }\end{array}$} & \multicolumn{2}{|c|}{ Method } & \multicolumn{2}{|c|}{ Method } \\
\hline & & & $\begin{array}{l}\text { Cystine } \\
\text { Content } \\
\mathrm{g} / 16 \mathrm{gN}\end{array}$ & $\begin{array}{c}\text { Cystine } \\
\text { Remains } \\
\% \text { of Total }\end{array}$ & $\begin{array}{l}\text { Cystine } \\
\text { Content } \\
\text { g/16 gN }\end{array}$ & $\begin{array}{c}\text { Cystine } \\
\text { Remains } \\
\% \text { of Total }\end{array}$ \\
\hline None & Flour & None & 1.10 & 100 & 1.40 & 100 \\
\hline Autoclaved & Flour & None & 0.55 & 50 & 0.85 & 61 \\
\hline None & Defatted Flour & None & 1.00 & 100 & 1.40 & 100 \\
\hline Autoclaved & Defatted Flour & None & 0.54 & 54 & 0.84 & 60 \\
\hline None & Glycinin & None & 1.20 & 100 & 1.48 & 100 \\
\hline Autoclaved & Glycinin & None & 0.86 & 72 & 0.99 & 67 \\
\hline None & Glycinin & Sucrose & 1.20 & 100 & 1.48 & 100 \\
\hline Autoclaved & Glycinin & Sucrose & 0.82 & 68 & 0.99 & 67 \\
\hline Autoclaved & Glycinin & D-Glucose & 0.82 & 68 & 1.01 & 68 \\
\hline Autoclaved & Glycinin & D-Xylose & 0.82 & 68 & 0.99 & 67 \\
\hline
\end{tabular}

also confirmed by another procedure, the chromatographic method of Schram et al. ${ }^{16)}$ (Table VI).

Regarding the cystine destruction in soybean oil meal or soybean protein, Evans et al. ${ }^{11)}$ considered that at least two possibilities exist as to why cystine was destroyed when soybean meal was autoclaved but not when Alpha protein or protein plus various carbohydrates or oil, which are constituents of the meal, were autoclaved. One possibility was that the microbiological procedure was not sensitive enough to detect all the cystine in Alpha protein. The other possibility was that part of the cystine of soybean protein is more resistant to heat destruction than the rest and that the labile cystine has been destroyed in the preparation of Alpha protein. Apparently, this was due to the use of a commercially isolated soybean protein (Alpha protein) by Evans et al., ${ }^{9 \sim 11)}$ and the protein contained less than half as much cystine as does the total protein of soybean meal, which indicated loss of cystine in preparation of Alpha protein. Therefore, it may be considered that the protein used by Evans et al. is not suitable for the purpose of evaluating cystine destruction.
It is apparent that cystine is the most heatlabile among the amino acids in soybean flour. In comparison with lysine, both the amino acids were partially destroyed by heat in the soybean products but the reaction differed, namely, the destruction of lysine was increased by addition of sugars to samples, whereas an addition of sugars to the samples does not increase cystine destruction except ES. Consequently, heating temperature or pressure is found to be the more critical factor for the stability of cystine.

The destruction of methionine.

No methionine was found to be destroyed in the present investigation (Table VII). These results corresponded with our earlier findings ${ }^{1,2)}$ and also with that of Evans et al. ${ }^{12}$ ) except that $8 \%$ of added DL-methionine was destroyed by autoclaving in the presence of sucrose. It is considered that the destruction reported by Evans et al. is due to the large amount of sucrose.

Evans et al. ${ }^{12)}$ reported that $32 \%$ of the total methionine was inactivated in heated soybean oil meal. The most important amino acids which are limiting in soybean with regard to 
human nutrition are sulphur containing claved soybean from nutritional point of view. amino acids. ${ }^{17)}$ From those mentioned above it is suggested that large amount of cystine destruction is the most critical factor in auto17) Food Agr. Organ. U. N. FAO Nutr. Studies, No. 16, Rome, 1957. 